Ferns of South Africa.- $\mathrm{SIM}^{6}$ has prepared a second edition of his Ferns of South Africa, bringing together in this convenient form much widely scattered information. The preliminary chapters deal with the following topics: ferns, parts of ferns, reproduction and propagation, cultivation, identification and preservation, the ferns of South Africa, the natural home of ferns. The bulk of the volume naturally is concerned with the descriptions of species. Attention is called to the fact that the number of species of ferns in South Africa is remarkably small compared with the whole flora. The present volume contains 220 species of ferns and fern allies, an increase of $4 \mathrm{I}$ species over the first edition, published in 1892 . The full descriptions and the numerous plates make the volume very complete for its purpose.-J. M. C.

Western wild flowers.-MARGARET ARMSTRONG ${ }^{7}{ }^{7}$ in collaboration with Professor J. J. THORnBER of Arizona, has prepared a popular field book describing and illustrating the "common wild flowers" west of the Rocky Mountains. The book is "popular," not merely in the selection of plants for description, but also in the absence of technical terminology. The author says that "almost all technical botanical terms have been translated into ordinary English." The drawings for the numerous illustrations have all been made from life, and, in connection with the "ordinary English" of the text, should enable the "general public" to identify the conspicuous plants in which it may have a casual interest.-J. M. C.

Plant life.-This title has been selected by $\mathrm{HALL}^{8}$ for a volume presenting the plant kingdom "to the amateur botanist and the lover of nature." As a consequence, the style is not technical, but appeals to general interest. The illustrations are numerous, and 50 of the 74 plates are colored. Some idea of the topics presented can be obtained from the chapter heads, which are in effect as follows: asexual plants, development of sex in plants and a study in evolution, seaweeds, fungi and lichens, archegoniates, phanerogamia, fossil plants, food of plants, perpetuation of the race, defenses of plants, ecology.J. M. C.

\title{
NOTES FOR STUDENTS
}

Origin of monocotyledony. - In an address delivered at the twenty-fifth anniversary celebration of the Missouri Botanical Garden, Coulter, ${ }^{9}$ because of continued studies on the origin of monocotyledony, chiefly in grasses,

${ }^{6}$ Sim, Thomas R., The ferns of South Africa. 2 d ed. 8 vo. pp. ix +384 . pls. 186. Cambridge University Press. 1915. 25 s.

7 Armstrong, Margaret, Field book of western wild flowers. I6mo. pp. $x x+$ 596. col. pls. 48. figs. 500. New York and London: Putnam, r9r5. \$2.00.

${ }^{8}$ Hall, Charles A., Plant life. 8vo. pp. xi+380. pls. 74. figs. 80 . London: A. \& C. Black. I915.

9 Coulter, J. M., The origin of monocotyledony. Ann. Mo. Bot. Gard. 2:175183. figs.9. $19 \mathrm{I}_{5}$. 
restated the conclusions previously arrived at from a study ${ }^{10}$ of Agapanthus umbellatus and some other monocotyls as follows: "In the embryogeny of both monocotyledons and dicotyledons, a peripheral cotyledonary zone gives rise to two or more growing points, or primordia; this is followed by zonal development, resulting in a cotyledonary ring or sheath of varying length. If both growing points continue to develop equally, the dicotyledonous condition is attained; if one of the growing points ceases to develop, the continued growth of the whole cotyledonary zone is associated with that of the other growing point, and the monocotyledonous condition is attained. In like manner, polycotyledony is simply the appearance and continued development of more than two growing points on the cotyledonary ring. It follows that cotyledons are always lateral structures, arising from the peripheral zone developed at the top of a more or less massive proembryo. This reduces cotyledony in general to a common basis in origin, the number of cotyledons being a secondary feature. The constancy in the number of cotyledons in a great group is no more to be wondered at than the same constancy in the number of petals developed by the petaliferous zone."

To those whose mental processes require a "type" for everything, the embryogeny of the grasses is very puzzling, because it does not conform to the hitherto accepted monocotyl "type" of embryogeny. The structures have received the names "scutellum," "epiblast," and "coleoptile." Early in the history of the subject the scutellum was recognized as the cotyledon. The epiblast was recognized as a second and rudimentary cotyledon from its first discovery until the time of SCHLEIDEN, who in I837 so clamorously dissented from this view that it was suppressed from the literature of the subject until I897, when VAN TIEGHEM, studying the embryogeny of grasses, reaffirmed that the epiblast is a second cotyledon. In the meantime HansteIn, followed by Famrntzin, had made a study of Alisma, which has a filamentous and therefore highly specialized proembryo, and fixed what has been almost universally regarded as the monocotyl "type" of embryo. Because of these first studies, the massive proembryo, so prevalent in monocotyledons, has been called the "aberrant type," although it is undoubtedly the more primitive and generalized, while the filamentous proembryo is the more specialized. About two-thirds of the grasses show a well marked second cotyledon. This second cotyledon is quite pronounced in those grasses which have a relatively long internode ("mesocotyl" of English anatomists) between the cotyledons and the "coleoptile" or bud-scale leaves.

COULTER shows that there is a progressive reduction of the second cotyledon until Zea Mays is reached, where the only external sign of the second cotyledon is a small hump opposite the functional cotyledon; but even here a small procambium is present, being exactly opposite the procambium of the

ro Coulter, John M., and LAND, W. J. G., The origin of monocotyledony. Bot. GAz. 57:509-519. pls. 28, 29. I9I4. 
functional cotyledon. The absence of a vascular strand in the smaller cotyledon has been used as evidence to prove that it is not a second cotyledon. The reviewer has no doubt that when a relatively great quantity of material shall have been studied a procambium will occasionally be found in the second cotyledon. It is unfortunately the habit of some investigators to make sweeping conclusions from an examination of a very small quantity of material.

The facts shown by this reinvestigation of the grasses are as follows: "The terminal cell of the proembryo forms a group of cells; the peripheral cells of the group develop the cotyledonary ring or sheath, on which two growing points appear. One of these growing points soon ceases to be active, and the whole zone develops in connection with the other growing point; but at the base of the growing cotyledon a notch is left by the checking of the growing point. This notch is really the space between the two very unequal cotyledons which surround the real apex of the embryo. The apex of the embryo is at the bottom of the notch, and not at the tip of the large embryo. This apex soon begins to form leaves, and the so-called stem tip appears issuing from the bottom of the notch, in a relation apparently lateral only because the two cotyledons are so unequal. Furthermore, when the stem tip is examined, it is found not to be a stem tip, but a cluster of leaves, whose rapid development has aborted one of the growing points on the cotyledonary zone. All this is very obvious in grasses and is equally obvious in any massive proembryo, but it escaped the earlier observers of filamentous proembryos."

The general conclusion is that "monocotyledony is simply one expression of a process common to all cotyledony, gradually derived from dicotyledony, and involving no abrupt transfer of a lateral structure to a terminal origin."W. J. G. LAND.

Anatomy of Helminthostachys. - In the third of his series of papers on the Ophioglossaceae, LANG ${ }^{\text {II }}$ gives the results of a reinvestigation of the anatomy of the rhizome of Helminthostachys, together with the details of the vascular connections of two branching specimens. In rhizomes of young plants, the xylem forms a solid strand of two kinds of tracheids; those of the outer part having pitted walls, while the inner elements are smaller and are spirally thickened. By comparison with the bases of branch steles, where a similar condition exists, and by examination of the origin of leaf traces, where the protoxylem becomes evident, it is shown that the two kinds of elements in the juvenile type of stele are outer and inner metaxylem, respectively; and that therefore the stele of Helminthostachys is mesarch even in the juvenile condition. The transition to the adult condition begins by the appearance of parenchyma cells among the tracheids of the inner metaxylem, thus forming a mixed pith. In the adult condition the stele is greatly expanded and the pith is large.

II LANG, William H., Studies in the morphology and anatomy of the Ophioglossaceae. III. On the anatomy and branching of the rhizome of Helminthostachys zeylanica. Ann. Botany 29:1-54. pls. I-3. figs. 7. I9I5. 


\section{$2 \mathrm{BHL}$ Biodiversity Heritage Library}

Land, W J G . 1915. "Origin of Monocotyledony." Botanical gazette 60(6), 497-499. https://doi.org/10.1086/331700.

View This Item Online: https://www.biodiversitylibrary.org/item/108949

DOI: https://doi.org/10.1086/331700

Permalink: https://www.biodiversitylibrary.org/partpdf/223722

\section{Holding Institution}

Missouri Botanical Garden, Peter H. Raven Library

\section{Sponsored by}

Missouri Botanical Garden

\section{Copyright \& Reuse}

Copyright Status: Public domain. The BHL considers that this work is no longer under copyright protection.

This document was created from content at the Biodiversity Heritage Library, the world's largest open access digital library for biodiversity literature and archives. Visit BHL at https://www.biodiversitylibrary.org. 